\title{
New onshore/offshore evidence of the Messinian Erosion Surface from key areas: The Ibiza-Balearic Promontory and the Orosei-Eastern Sardinian margin
}

\author{
Agnès Maillard ${ }^{1, *}$, Virginie Gaullier ${ }^{2}$, Carine Lézin ${ }^{1}$, Frank Chanier ${ }^{2}$, Francis Odonne ${ }^{1}$ and Johanna Lofi ${ }^{3}$ \\ ${ }^{1}$ Géosciences Environnement Toulouse (GET), Observatoire Midi-Pyrénées, Université de Toulouse, CNRS, IRD, UMR 5563, 14, \\ Avenue E. Belin, F31400 Toulouse, France \\ ${ }^{2}$ Univ. Lille, CNRS, Univ. Littoral Côte d'Opale, UMR 8187, LOG, Laboratoire d'Océanologie et de Géosciences, F59000 Lille, France \\ ${ }^{3}$ Univ. Montpellier, CNRS, UMR 5243, Laboratoire Géosciences, 34095 Montpellier, France
}

Received: 16 July 2019 / Accepted: 2 March 2020

\begin{abstract}
As the Messinian sea-level draw down associated with the Messinian Salinity Crisis is still questioned, we propose to show that the widely spread erosion surface affecting the Mediterranean margins is indeed linked to an exondation demonstrated from offshore and onshore data. Our study presents a comprehensive onshore to offshore correlation of the Messinian erosional surface. It is focused on small drainage systems or interfluve areas, outside of evaporite basins or incised canyons, where the Messinian erosion had not yet been studied previously: around Ibiza on the Balearic Promontory and around Orosei on the Eastern Sardinian margin, Tyrrhenian Basin, both areas where new offshore data were recently acquired. We show that the late Messinian erosion formed in subaerial settings, as testified by evidence of continentalization events, and attests for a regression phase that was correlated from the offshore continental slopes to the onshore paleo-platforms in both areas. Characteristics of this erosion in both study areas strengthen the scenario with at least one important low-stand sea-level for the Messinian Salinity Crisis with evaporites subbasins lying at different depths and possibly disconnected.
\end{abstract}

Keywords: Messinian Salinity Crisis (MSC) / Northwestern Mediterranean / erosion surface / Ibiza / Eastern Sardinian margin

Résumé - Découverte de la surface d'érosion messinienne onshore/offshore dans deux lieux clés: le Promontoire Baléares (lbiza) et la marge est-sarde (Orosei). Depuis la découverte de la crise de salinité messinienne dans les années 70, le scénario proposant une chute importante du niveau marin associé à la mise en place des évaporites dans les plaines abyssales de la Méditerranée est régulièrement remis en cause. Nous montrons que la surface d'érosion affectant l'ensemble des marges est en effet liée à une émersion que l'on peut suivre à terre. Les observations présentées à terre s'attachent aux zones d'interfluves en dehors des bassins évaporitiques périphériques, là où la surface d'érosion messinienne n'a pas été étudiée : autour de l'île d'Ibiza dans les Baléares et autour d'Orosei sur la marge est-sarde. La surface d'érosion messinienne y est mise en évidence pour la première fois. Les données de sismique haute résolution récemment acquises dans ces deux zones nous permettent de présenter des corrélations terre-mer. Des évènements marquant clairement une continentalisation caractérisent la limite Mio-Pliocène dans les deux régions et atteste une phase régressive que l'on peut suivre des paléo-plateformes continentales à terre aux pentes du domaine offshore. Ces observations apportent des éléments pour étayer un scénario de la crise avec un bas niveau marin et des bassins évaporitiques à différentes paléo-bathymétries, possiblement déconnectés les uns des autres.

Mots clés : Crise de salinité messinienne / Méditerranée nord-occidentale / surface d'érosion / Ibiza / marge est-sarde

\footnotetext{
*Corresponding author: Agnes. MAILLARD-LENOIR@Get.omp.eu
} 


\section{Introduction}

The Messinian Salinity Crisis (MSC) in the Western Mediterranean Sea resulted first in evaporites precipitation in peripheral shallow basins ("Primary Lower Gypsum": PLG). Then, evaporite precipitation shifted to the deepest depocentres in the central bathyal domains with a "deep basin trilogy"; Hsü et al., 1973; Ryan and Cita, 1978; Lofi et al., 2011; Manzi et al., 2018), while erosion affected Mediterranean drainage areas with incisions of deep subaerial valleys (Chumakov, 1973; Clauzon, 1973; Barber, 1981; Savoye and Piper, 1991). This erosion is also observed offshore over most of the present-day Mediterranean margins as a widespread surface at the base of the Pliocene-Quaternary series and incising in the pre-MSC series, called the Margin Erosion Surface (MES) (Guennoc et al., 2000; Lofi et al., 2005; Bache et al., 2009; Lofi et al., 2011). It has been related to a drop of debated amplitude of the sea-level during the peak of the crisis, from 5.6 to 5.32 Ma (Cita and Ryan, 1978; Clauzon, 1982; Gautier et al., 1994; Rouchy and Caruso, 2006; Ryan, 2009; Manzi et al., 2013). According to some scenario (CIESM, 2008), this erosion surface should therefore be continuous on the paleo-platforms, and subaerial. However, high amplitude sea-level drawdown is still debated (Hardie and Lowenstein, 2004; Roveri and Manzi, 2006) and new results based mostly on geochemical analysis favor an interconnection of all the Mediterranean subbasins during the MSC, therefore suggesting that evaporites precipitated from the same water-body at high sea-level (Roveri et al., 2014; Gvirtzman et al., 2017; Manzi et al., 2018).

The MES is well documented in the large fluvial systems such as the Rhone, Ebro, and Nile where the incision is observed from downslope, i.e. on the continental slopes offshore (Lofi et al., 2005; Bache et al., 2009; Urgeles et al., 2011; Pellen et al., 2019), to upslope, onland, up to Lyon in the Rhone Valley or up to Assouan in the Nile Valley (Chumakov, 1973; Clauzon, 1973; Guennoc et al., 2000).

In the peripheral shallow basins, currently onshore, the MES is also identified but its stratigraphic position remains uncertain and debated (Roveri et al., 2014; Clauzon et al., 2015). Indeed, the offshore MES has been tentatively correlated to several key surfaces identified in onshore successions, each of them having different relationship in regard to the Primary Lower Gypsum (PLG) and to the distinctive Late Miocene units, particularly the Terminal Carbonate Complex (TCC; according to Esteban, 1979; see Clauzon et al., 2015 for a review).

Elsewhere, in small or diffuse drainage systems, or interfluve areas, the MES has rarely been studied (Cornée et al., 2008). To evidence the MES in such places, we aimed to unequivocally identify the erosion, allowing drawing of a complete onshore-offshore sketch.

Offshore, the extension of the MES (i.e. the erosion surface down to the transition to the MSC-deposits) has been followed all along the northwestern Mediterranean margins (Fig. 1), in the framework of an integrated study of several key-areas in different settings (Lofi et al., 2011, 2018). In this scientific context and with a land-sea approach, we focused on two areas, respectively, the Balearic Promontory to the West, and the Eastern Sardinian margin in the Tyrrhenian Basin to the East; both areas where the offshore MES has already been studied
(Maillard et al., 2014; Driussi et al., 2015; Lymer et al., 2018). Onshore, we document the MES for the first time:

1 around Ibiza on the Balearic Promontory, within the Miocene-Pliocene series outcropping on the NE part of the island, that are for the first time interpreted in the light of the MSC;

2 around Orosei on the Eastern Sardinian margin, Tyrrhenian Basin, where the MES was unknown.

Finally, the correlation of the MES between the offshore continental slopes and the onshore paleo-platforms in both areas can be proposed.

\section{Data and method}

Offshore seismic lines and maps result from a large seismic database including academic seismic profiles obtained during several scientific cruises and oil-industry profiles, improved by high-resolution seismic profiles acquired recently along the Eastern Sardinian margin and SE Corsican margin during the "METYSS 1" and "METYSS 3" cruises, in June 2009 and April 2011, respectively (Gaullier et al., 2014) and on the Balearic Promontory during the "SIMBAD" cruise in January 2013 (Maillard et al., 2014; Driussi et al., 2015) (Fig. 2). The profiles were acquired on the R/V "Téthys II" (INSU-CNRS/CIRMED) with a source that consisted of a mini-GI (SODERA) air gun and a receiver that was a 6-channel 25-m streamer. Data were processed using the Géovecteur ${ }^{\circledR}$ software package. Locally, we can differentiate between different types of seismic units on the basis of their acoustic facies and geometries. Some of the reflections were tied to wells and enabled to correlate seismic units to stratigraphic layers (Gaullier et al., 2014; Driussi et al., 2015; Lymer et al., 2018). They were extended laterally on the study areas and landward as shallow as possible. On the margins, the pre-MSC units are identified thanks to truncations below a usually high amplitude reflection (Fig. 3). Above, the post-MSC unit linked to the base of the Pliocene shows a nearly transparent seismic facies as observed all over the Northwestern Mediterranean (Fig. 3). It passes progressively upward to higher amplitude parallel reflections. On these bases and from correlation to some industrial wells or deep drilling sites, we could identify the MES on the seismic lines with great confidence. To present offshore maps of the MSC markers in both study areas, we used former works of the same research team (Gaullier et al., 2014; Maillard et al., 2014; Driussi et al., 2015; Lymer et al., 2018; Fig. 2) and added some details, looking carefully on some lines. Time-depth conversion is done using a velocity of $1500 \mathrm{~m} / \mathrm{s}$ in water and $2000 \mathrm{~m} / \mathrm{s}$ in Pliocene-Quaternary sediments.

Onshore, we investigated the lateral continuity of the MES through mapping the erosional surface at the base of the marine Pliocene deposits in northeastern Sardinia and by the detailed stratigraphic analysis of the late Neogene deposits in northeastern Ibiza Island (Lézin et al., 2014, 2017; Giresse et al., 2015). In all localities, we undertook a detailed analysis of the stratigraphic records with emphasis on the observed unconformities. Our field work is mainly based on mapping, logging and sampling for biostratigraphy to establish the late 


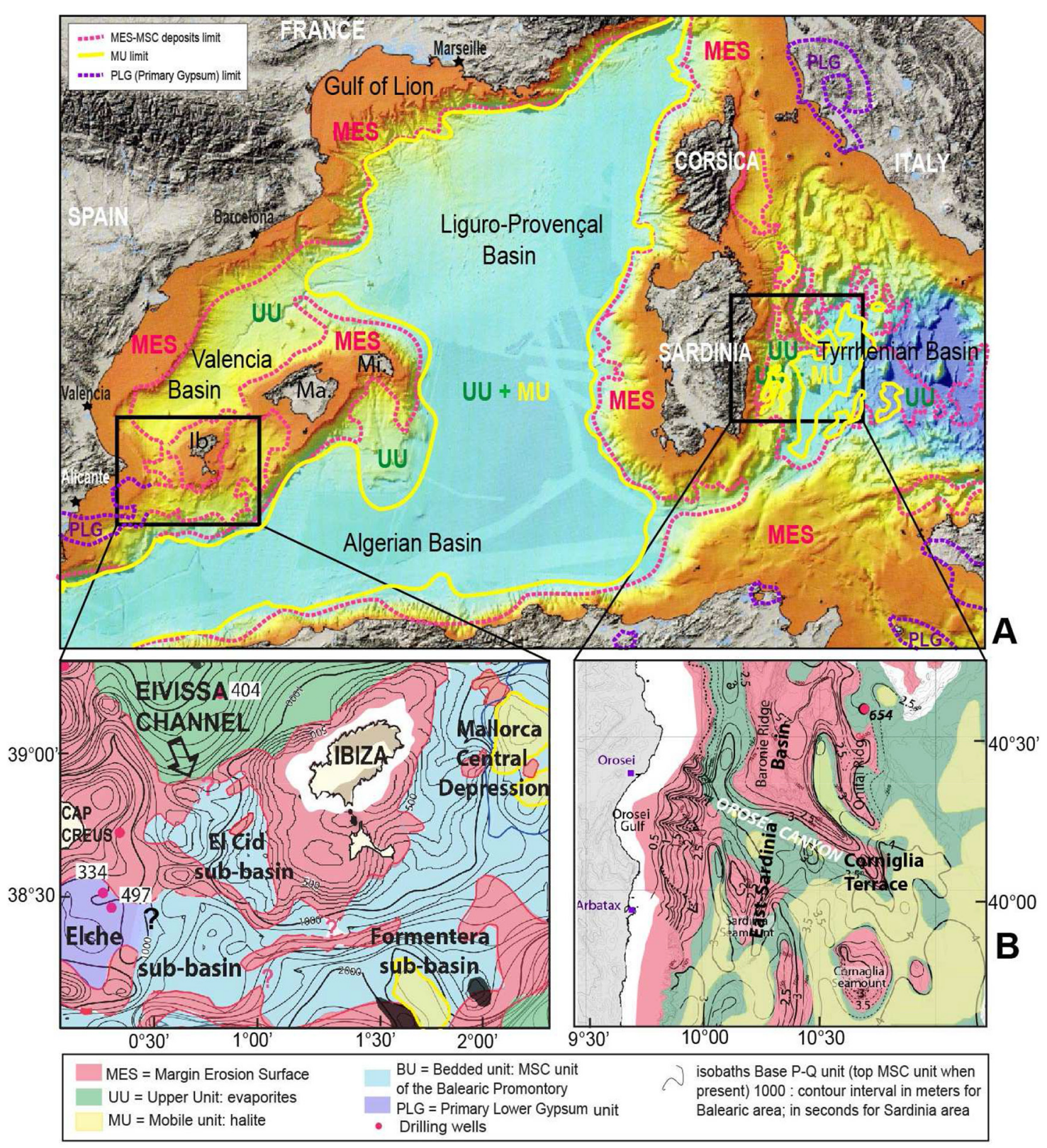

Fig. 1. Extension of the Messinian Salinity Crisis (MSC) markers and the Margin Erosion Surface (MES) in Western Mediterranean Sea. A. Regional bathymetric map (from Brossolo and Mascle, 2008) with the location of the two study areas (black rectangles). Margin Erosion Surface (MES) downslope limit, in pink dotted line, is also the upper limit of the MSC units extension. B. Zooms on the two study areas: maps of Ibiza (left) and East Sardinia (right). Isobaths draw the base of the Pliocene-Quaternary unit in its present-day morphology. UU=Upper Unit; $\mathrm{MU}=$ Mobile unit; $\mathrm{BU}=$ Bedded unit; $\mathrm{PLG}=$ Primary Lower Gypsum unit.

Neogene tectono-sedimentary evolution. These works were partially presented for the Orosei area in Giresse et al. (2015) but never analyzed in term of the MSC. For the Ibiza onshore it has never been published.

\section{Offshore MSC units and erosional surfaces}

In the Western Mediterranean deep basins, the evaporites related to the MSC have been identified as three distinct seismic units also called Messinian "deep basins trilogy"
(Hsü et al., 1973; Montadert et al., 1978). This trilogy is composed, from top to bottom, of the Upper Unit (UU, corresponding to the former "Upper Evaporites"), the Mobile Unit (MU, corresponding to the former "thick salt layer") and the Lower Unit (LU, corresponding to the former "Lower Evaporites") (Lofi et al., 2011). It is an aggrading sequence infilling the topographic preexisting lows. These units thin towards the passive margins of the Western Mediterranean basin, pinch out at about 2 to $3 \mathrm{~s}$ twtt-deep, and pass laterally upward to the MES (Lofi et al., 2011, 2018; Bache et al., 2012; Leroux et al., 2015). Another unit has been identified recently in the intermediate-depth basins called Bedded Unit (BU) 


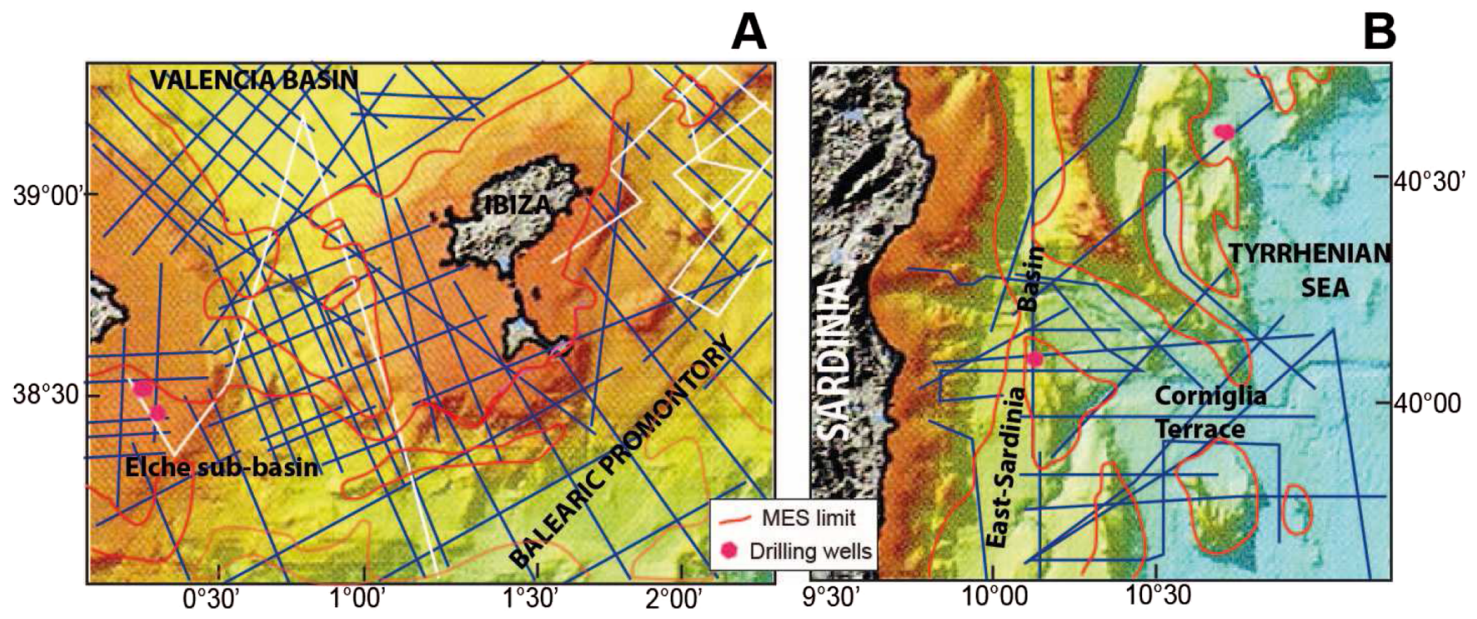

Fig. 2. Position of the seismic lines used in this study on the bathymetric map (after Brosolo and Mascle, 2008). A: for the Ibiza area, white lines: the SIMBAD high resolution lines and dark blue lines: former industrial and academic lines; B: for the Orosei area, dark blue lines: the "METYSS 1" and "METYSS 3" high resolution seismic lines.

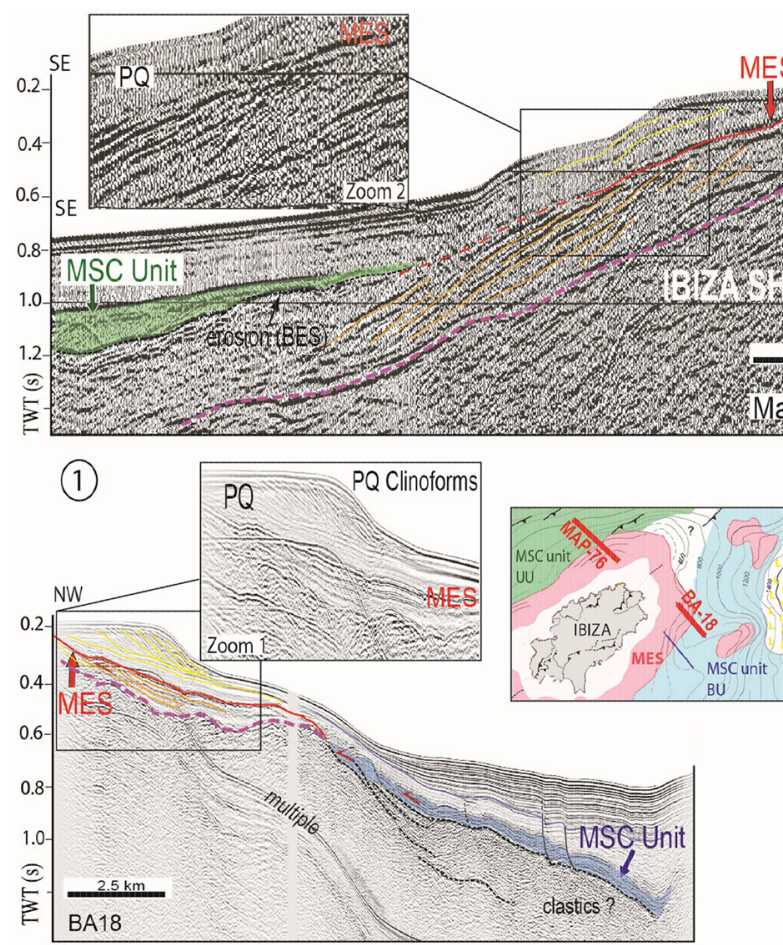

(2)
A. B.

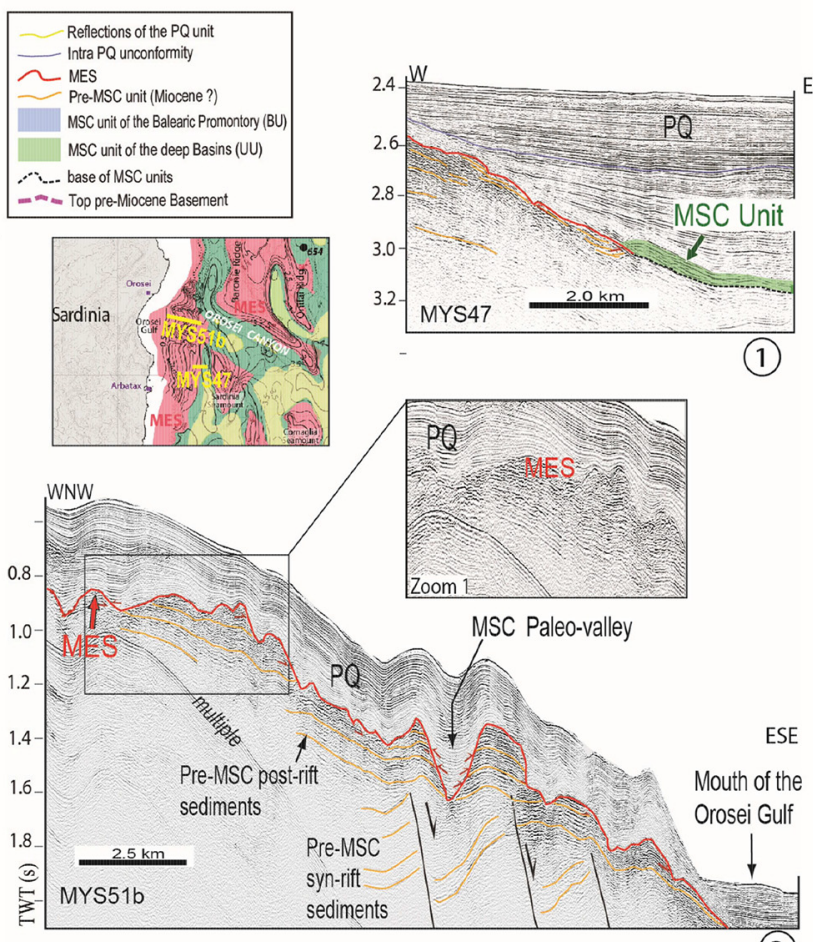

(2)

Fig. 3. Seismic lines displaying the Margin Erosion Surface offshore. A. Seismic profiles showing onlap of the MSC unit on the MES, for the Valencia Basin (UU; industrial line, A-1) and the Balearic Promontory (BU; academic Simbad-cruise high-resolution line, A-2). Note that UU is onlapping mostly horizontally and BU is tilting and gliding on a basal decollement surface. B. Seismic profiles showing the MES on the EastSardinia margin, onlap of MSC unit (UU) on the MES (B-1); rugged morphology of the MES in Orosei valley (B-2). Both areas show truncation of pre-MSC units. Vertical exaggeration of the lines is approximately x 2.5 for the pre-MSC unit and x 5 for the Messinian to Quaternary units. Each line is located on its respective area map.

(Lofi et al., 2018), located in between the deep basins evaporite units and the peripheral basins filled with the PLG unit (Fig. 1).

The Balearic Promontory is a continental rise $(500 \mathrm{~km}$ long, $120 \mathrm{~km}$-wide) which includes the Balearic Islands. Although located between extensional basins, the Valencia continental Basin to the North, the Algerian and the Provençal oceanic basins to the South and East respectively, it is considered as the easternmost prolongation of the Betic thrusts belt (Sanz De Galdeano, 1990; Roca, 2001; Sabat et al., 2011; Fig. 1A). Over the offshore Balearic Promontory, some thin MSC unit (BU) has been recently evidenced (Maillard et al., 2014; Driussi et al., 2015), and appear widely distributed in 

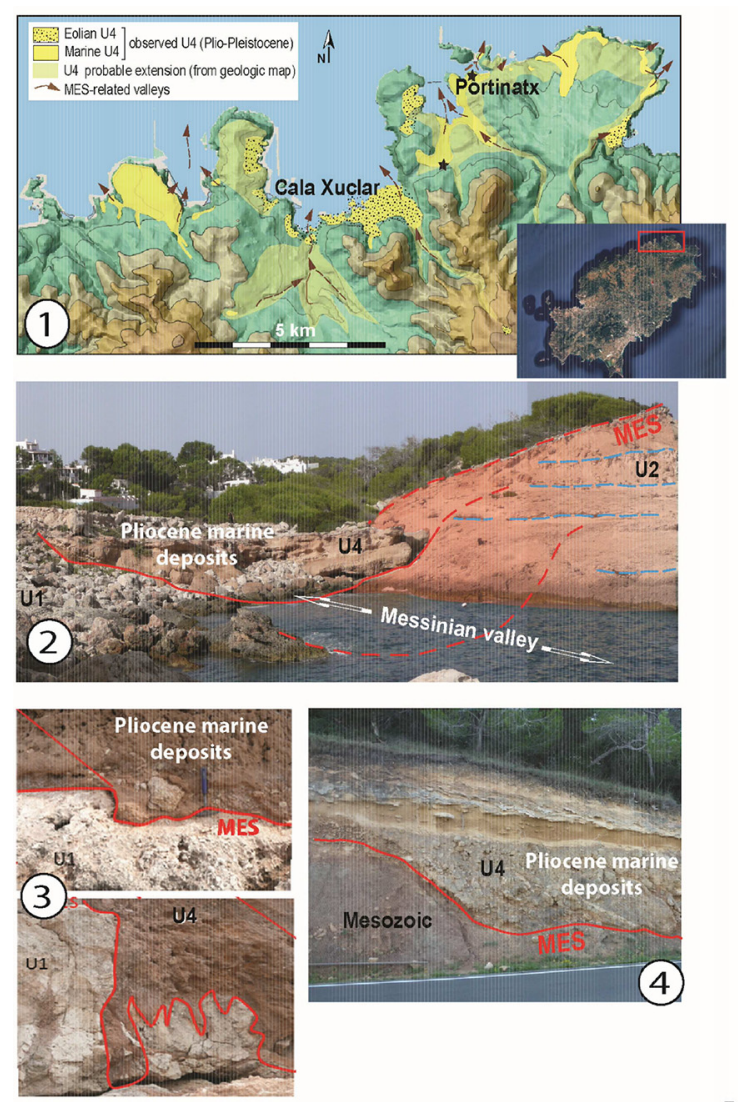

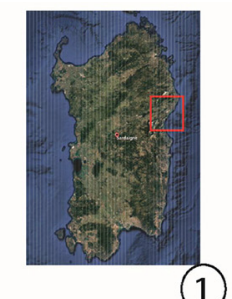

(1)
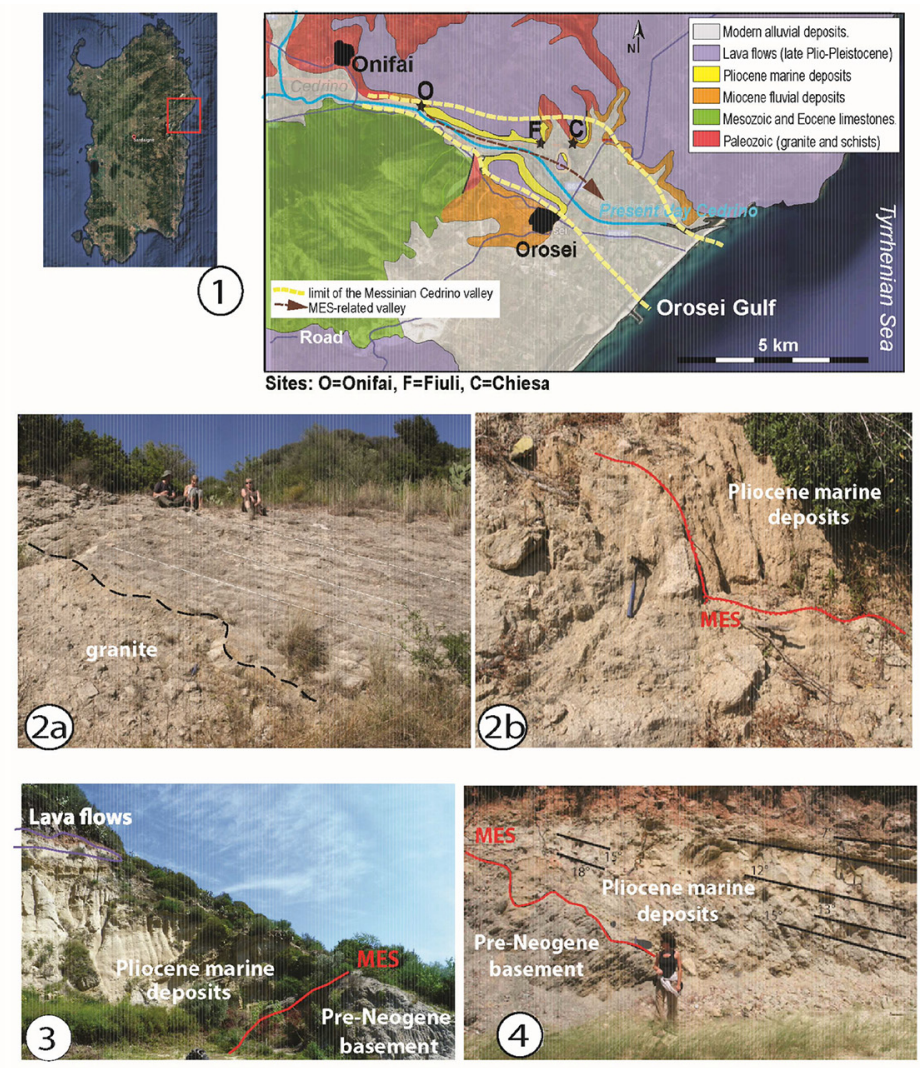

A. B.

Fig. 4. Pictures displaying the Margin Erosion Surface onshore. A. The Northeastern part of Ibiza Island. A-1: Map showing extension of U4 Plio-Pleistocene unit infilling the Messinian valleys (DEM of present-day topography). A-2: Incision of the MES in U1 and U2 Miocene units at Portinatx (Ibiza Island), showing a small valley filled with Pliocene deposits (location on map 4A-1). A-3: Close-up view of MES in Portinax. A4: MES incising Mesozoic rocks (black star located on map 4A-1). B. Orosei, Central Eastern Sardinia. B-1: Schematic geological map of the Orosei area with the location of marine Pliocene outcrops (modified from Beccaluva et al., 1983) and location of the MSC valley. B-2a: Chiesa Site (location on map 4B-1): graded beds of poorly sorted torrential deposits on top of the granitic basement (granite covered by a layer of chaotic granitic angular blocks from rock avalanches). Black dashed line: unconformity between Paleozoic basement and Miocene continental deposits (Alpine-Pyrenean unconformity). B-2b: Miocene continental deposits are incised by an erosional surface that is covered by Pliocene marine deposits. This erosional surface is therefore attributed to the MES (in red). B-3: Fiuli Site (location on map 4B-1): Pliocene shallow marine sandy sediments resting in unconformity on top of the pre-Neogene basement (Red line: MES). B-4: View of the MES (red line) below Pliocene marine deposits at Onifai Site (location on map 4B-1).

small intermediate-depth sub-basins (Fig. 1B). On the Alicante margin near Ibiza Island, borehole analyses have shown that this unit corresponds in this sector of the promontory to the PLG (Fig. 1; Ochoa et al., 2015). Although no peripheral evaporites basin has been described in the Balearic Islands, gypsum, possibly correlated to the PLG, was drilled below the airport in the Palma basin in Mallorca Island and extends offshore (Rosell et al., 1998; Mas et al., 2012; Maillard et al., 2014). The MSC-related unit of the offshore Balearic Promontory could then be composed, at least partly, of Primary Lower Gypsum, and thus differ from that of the surrounding deep basins filled with the deep basin evaporites (MU and UU: Fig. 1).

The MES has been particularly well defined on the Valencia margins, where it was mapped and drilled by numerous wells (Mauffret et al., 1978; Lanaja, 1987; Field and Gardner, 1991; Escutia and Maldonado, 1992; Maillard et al., 2006; Maillard and Mauffret, 2006; Urgeles et al., 2011; Pellen et al., 2019). In the Valencia basin, the MSC unit (UU) onlaps the MES at about $2 \mathrm{~km}$-depth on the northern Catalan margin (Garcia et al., 2011; Pellen et al., 2016) but thins towards the Balearic Promontory and drapes the slope of the Balearic Islands, pinching out on the MES at a mean depth of $0.8 \mathrm{~s}$ twtt, i.e. at about $700 \mathrm{~m}$ depth (Fig. 3A-1).

Around Ibiza, the MES exists everywhere as deep as $500 \mathrm{~m}$ (Fig. 1B). It truncates pre-MSC units and extends below Pliocene-Quaternary clinoforms building the present-day shelf (Fig. 3A-2). Downslope, it passes to the thin MSC unit (BU) draping all the depression areas of the Promontory. Some clastic units (Lofi et al., 2011) could exist below the MSC unit, as chaotic seismic facies are often observed, as shown in the Valencia Basin (Maillard et al., 2006; Pellen et al., 2016).

From the Valencia basin, the MES can be followed continuously through the Gulf of Lion, the Corsica margins and until the Sardinian passive margins (Fig. 1A; Sage et al., 2005; Cornée et al., 2008; Thinon et al., 2016; Lymer et al., 
2018). In the study area (Fig. 1B), the Eastern Sardinian margin deepens rather abruptly from the Sardinia shelf, breaking toward the abyssal Tyrrhenian Basin, crossing the 200-2000 m water depth East-Sardinia Basin parallel to the coast and the wide and flat Cornaglia Terrace with water depths ranging from $2000 \mathrm{~m}$ to $3000 \mathrm{~m}$. Offshore of the Orosei Gulf, these domains are incised by the Orosei Canyon. The Tyrrhenian Sea is a back-arc basin related to the eastward migration of the Apennine subduction system from Oligo-Miocene to present-day (Malinverno and Ryan, 1986; Gueguen et al., 1998; Sartori et al., 2001; Doglioni et al., 2004; Jolivet et al., 2006; Prada et al., 2016). Recent observations reveal however that the Eastern Sardinian margin was already segmented in horsts and grabens during the MSC and imply that the MSC occurred after the end of the rifting (Lymer et al., 2018).

On the shelf, the MES progressively deepens from the coast towards the East Sardinia Basin (Lymer et al., 2018; Fig. 1B). There, the MES displays rough and valley-like morphologies (Figs. 1B and 3B-2). The basal-Pliocene unit, characterized by its low amplitude/nearly transparent seismic facies, is directly located above the MES and fills the MSC paleo-valleys. The depth of incision of the MSC valleys is generally less than $100 \mathrm{~m}$ (assuming a mean internal velocity of $2000 \mathrm{~m} / \mathrm{s}$ in the PQ unit). The main MSC paleo-valley has incised the pre-MSC series by approximately $280 \mathrm{~m}$ (Fig. 3B-2). Downslope, the MES is markedly smoother (Fig. 3B-1). It passes laterally to the MSC Unit (UU) near the bottom of the East-Sardinia Basin at $2.9 \mathrm{~s} \mathrm{twtt}$, i.e. at about $2.3 \mathrm{~km}$ depth. The MES thus exists much deeper than on the Balearic Promontory, showing an onlap of the $\mathrm{UU}$ at a depth compatible to that usually seen around the NW Mediterranean margins (i.e. 2 to $3 \mathrm{~km}$, Lofi et al., 2011; Leroux et al., 2019). The clastic unit, which is widely present in other Mediterranean basins, is visible only very locally in our study area, along the flank of some structural highs.

\section{Onshore MSC units and erosional surfaces}

\subsection{Ibiza Island, Balearics}

During the late Miocene times (post-Betic phase), only a small area in the NE of Ibiza registered shallow marine sedimentation and transition to continental deposits (DurandDelga et al., 1993). We identified the following four Late Miocene to Plio-Pleistocene sedimentary units (U1-U4), from bottom to top (Figs. 4A and 5A) (Lézin et al., 2014, 2017).

\subsubsection{Description}

Unit U1 is mainly composed of fossil-rich limestones (benthic foraminifera, corals, rhodoliths, vermetids, cerithids...) and locally Cnidarians-rich limestones with abundant reworked Tarbellastrea sp. accumulated in shallow marine environments (Fig. 5A).

Unit U2 with a conical shape sets up along $\mathrm{N} 70^{\circ}$ to $\mathrm{N} 110^{\circ}$ faults. The proximal part of the sedimentary alluvial fans is composed of polygenic detrital material (metric to plurimetric) deriving from Mesozoïc basement erosion. The middle part of the fan is characterized by decimetric layers composed of subangular centimetric pebbles that alternate with conglomerates to normal graded coarse sandstones, pink siltstones with microcodium and root traces (Fig. 5A) and marls with wellpreserved benthic foraminifera and reworked planktonic foraminifera. Braided fluvial channels, hydromorph paleosols, and sheet flood deposits attest continental and/or nearshore conditions, while the paleontological content of the argillites with foraminifera indicates marine environment. In the distal part, only shallow marine environment is recorded. Unit U2 is a clastic unit set up by gravitational and fluvial processes in nearshore environment allowing the edification of the coastal alluvial fans. It is controlled by the development of synsedimentary extensional faults (Lézin et al., 2017).

Unit U3 is mainly carbonated with oolithic grainstone and microbialites (stromatolites and thrombolites, Fig. 5A) developed in shallow marine environment. These deposits are deformed by synsedimentary large scale boudinage structures (Odonne et al., 2019) and are locally overlain by marly series with roots traces, microcodiums attesting to their continental origin (paleosol).

An important erosion and karstification surface incises these three units (Figs. 4A-2 and 4A-3), down to the underlying Mesozoic units (Fig. 4A-4). This erosion/dissolution surface is locally covered by Unit U4 formed by shallow marine calcarenites with gastropods, benthic and planktonic foraminifera (e.g. Globorotalia puncticulata and Globigerinoides extremus determined by F. Sierro, see Lézin et al., 2017), red algae or biodetrital sands with well sorted grains, Helix gastropods and cross-beddings with a dip greater than $30^{\circ}$ testifying an eolian depositional context (Figs. 4A and 5A).

\subsubsection{Interpretation}

The Miocene units show common characteristics with other Tortonian-Messinian units known in Mallorca or peripheral MSC Spanish basins such as in Sorbas Basin. Unit 1 presents strong facies similarities with the reef complex previously described in Mallorca Basin (Pomar et al., 1996, Pomar, 2001) and therefore could be Late Tortonian to Lower Messinian in age. From its characteristic facies, Unit 3 can be interpreted as the TCC (Terminal Carbonate Complex) found elsewhere onland Spain (Esteban et al., 1996; Riding et al., 1999; Cornée et al., 2004; Braga et al., 2006; Soria et al., 2008; Roveri et al., 2009; Lugli et al., 2010), and dated from 5.67 to $5.54 \mathrm{my}$ (Bourillot et al., 2010). Both Units 1 to 3 were deposited in shallow water or nearshore environment and record a transgressive general trend.

After the deposition of the TCC (Unit 3), the development of paleosols and the important erosion and karstification surface attests a major relative sea-level fall. The marine U4 was sampled and contains planktonic foraminifera attributed to lower Pliocene (younger than $4.7 \mathrm{my}$ ). U4 marine unit records a reflooding, with a sea level close to that recorded during the deposition of the TCC, that must be linked to the regional Zanclean reflooding of the West Mediterranean Basin at the end of the MSC.

The aeolian biodetrital sands have been assigned to the upper to middle Pleistocene in Cala Xuclar (Fig. 4A-1; Del Valle et al., 2016). Moreover, if U4 is mostly found locally onlapping the MES in valleys carved in the above units (Fig. 4A), it also rests as thin layers on top of the Late Miocene cliffs, reaching the altitude of $60 \mathrm{~m}$ and attesting for the high relative Pliocene sea-level. According to Miller et al. (2005), 

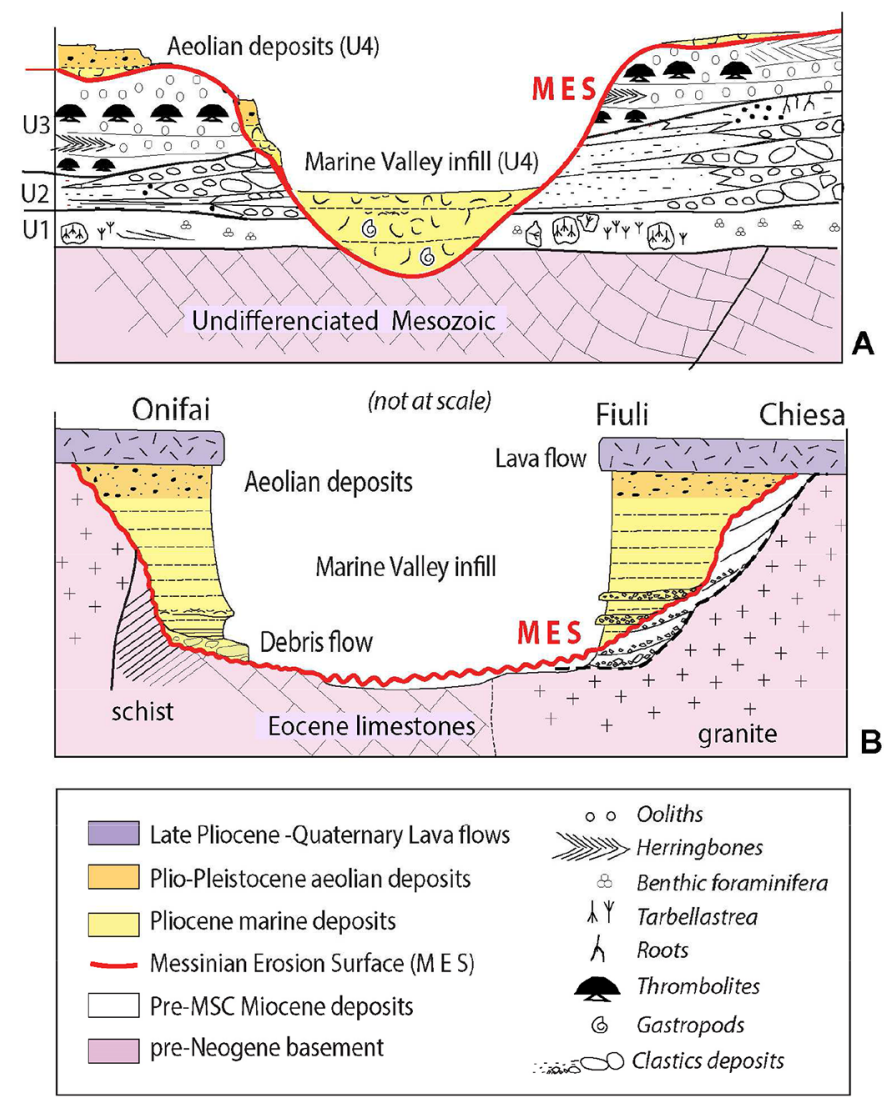

Fig. 5. Schematic representation of onshore stratigraphy illustrating the geometric relationship between pre- and post- MSC units below and above the MES. 4A shows the Ibiza sketch: Late Miocene units laying in unconformity on Mesozoic carbonate basement and the MES drawing a valley filled with U4, as in Portinatx. 4B displays the East-Sardinian sketch: various types of eroded basement, reduced pre-MSC Miocene (?) detritals witnesses of continentalization and well developed marine Pliocene filling the MES. See Figure 3 for locations.

the upper Zanclean sea level was at $20 \mathrm{~m}$ above the present day sea-level. Considering these values, a possible uplift of about $40 \mathrm{~m}$ should be consider.

We, therefore, assume that the exondation is related to the peak of the Messinian Salinity Crisis, corresponding to the MSC drawdown. The resulting strong erosion and karstification of the Upper Miocene and Mesozoic series are thus the MES (Fig. 4A-3), that has cut some small valleys then filled by the marine part of U4 (early Pliocene). The onshore valleys are correlated to coastal reentrants, called "calas" in Spain, which reflects the present-day landscape (Fig. 4A-1). This onshore Messinian diffuse erosion network, due to the absence of an important drainage system in Ibiza, must be connected to the MES observed on the Ibiza offshore upslope domain.

\subsection{Orosei Area, eastern Sardinia}

Recent onshore field investigations aimed to identify and characterize the erosion surface below the Pliocene marine deposits in the Orosei area, along the Cedrino River, eastern Sardinia (Fig. 4B).

\subsubsection{Description}

In this area, the pre-Neogene basement is mainly made of Hercynian granitic rocks and minor schists with locally a Mesozoic to early Cenozoic sedimentary cover (mainly platform limestones) that has been deformed during Pyrenean-Alpine orogeny (Dieni et al., 2008). Pre-Neogene basement along the valley of Cedrino is covered from upstream to downstream by chaotic blocks, followed by accumulations of conglomerate and polygenic or monogenic breccias and arenaceous coarse sandstones reaching up to $40 \mathrm{~m}$ in thickness. These clastic deposits evolve upward and laterally (toward the present-day coast-line) to torrential and then fluvial deposits with sequences of channelized sand and rounded pebbles (Figs. 4B-2 and 4). These continental clastic deposits are locally observed unconformable over the Eocene limestones, and they are considered as Miocene in age on the basis of similar facies in other areas of Sardinia (Calvino et al., 1972; Dieni et al., 2008). They are deeply incised by a Paleo-Cedrino valley, and subsequently filled up with marine fine sandy deposits, early Pliocene in age (Giresse et al., 2015; Fig. 5B). The erosion surface crosscuts not only the Miocene clastics but incises also the Mesozoic and Paleozoic basement (pre-Neogene basement, Figs. 4B-3 and 4B-4). Over this major discontinuity, the Pliocene sedimentary unit starts locally with some thin debris-flow deposits. The debris-flow reworked basement blocks including elements of nummulitic Eocene limestones in a fine-grained marine matrix including bioclasts and foraminifera (Fig. 4B-4) or dominated by granitic clasts (Fig. 4B-3). The sedimentation rapidly evolves into a fine sandy marine formation (Fig. 5B), up to $30 \mathrm{~m}$ thick, highly bioturbated and containing occasional shelly gravel beds, 20 to $30 \mathrm{~cm}$-thick. It includes mainly oysters, pectens, spines of sea urchins, gastropods and various benthic and planktonic microfauna that permitted to refine the age of the oldest exposed marine deposits over the erosion surface (Fig. 4B-3). The presence and common occurrence of Globorotalia puncticulata (FO 4.52 Ma; LO 3.57 Ma; Sierro et al., 2003) in the basal beds of the Pliocene marine formation attests an age younger than 4.52 Ma for this formation (Giresse et al., 2015). These Pliocene deposits are covered by late Pliocene to Quaternary lava flows that allowed the preservation of the Pliocene deposits (Calvino et al., 1972; Beccaluva et al., 1983; Figs. 4B-3 and 5B).

\subsubsection{Interpretation}

The observed sections show that the main erosion surface corresponds locally to a stratigraphic gap between Eocene and Early Pliocene deposits. The post-tectonic unconformity of the Pyrenean-Alpine orogeny is comprised in this time interval. However, in some localities (e.g. "Chiesa", Fig. 4B-2), the prePliocene erosion surface also incises some Miocene continental clastic deposits that are lying in unconformity over the postorogenic basement. Thus, there are two successive erosion surfaces in the Orosei area: the first one being linked to the end of Alpine-Pyrenean orogeny in Sardinia in the Late Eocene (e.g. Dieni et al., 2008), about c.40-35 Ma ago (Fig. 4B-2a), and the second one, stratigraphically positioned between the Miocene and the early Pliocene deposits (Fig. 4B-2b), having developed during the main Messinian event. This second remarkable surface is therefore interpreted as the MES (Fig. 5B). 


\section{Discussion-implications}

\subsection{Subaerial exposure and gravity-driven destabilization}

The MES is linked to continental processes and thus occurred in subaerial conditions. Both study areas display differences but also similitudes. In Ibiza Island, the major relative sea-level fall is recorded after the deposition of the TCC (U3 unit) and is evidenced by continental markers: the MES and locally the formation of paleosols at the top of the TCC (Lézin et al., 2017). High amplitude sea level change is also considered a likely trigger for gravity-driven instabilities such as bending soft deformation affecting U3 (Odonne et al., 2019). If it is difficult to appraise the exact chronology between the MES, the gravity instabilities in continental context and the paleosols, they all postdate the Late Miocene marine deposits and they are all evidence for subaerial events during a timeinterval linked to the low-stand sea-level (MSC peak). Gravitational deformation should be regarded in relation to large-scale processes of margin collapse during Messinian sealevel drawdown, proposed elsewhere in the Mediterranean Basin (Lofi et al., 2005; Del Olmo et al., 2011; Bache et al., 2015; Cameselle and Urgeles, 2017; Micallef et al., 2018). If such subaerial destabilization has been evidenced on the offshore slopes, similar examples from the shelf remain poorly documented, except where PLG evaporites are present in the pre-MSC late Miocene succession, allowing gliding (Cyprus: Orszag-Sperber et al., 2009; Sorbas: Bourillot et al., 2010; Clauzon et al., 2015). Onshore Eastern Sardinia margin, the youngest pre-MSC marine series is Eocene in age. Consequently, we assume that exondation lasted long and that the Miocene continental clastics deposition could have started before the end of the Miocene and thus, it cannot be undoubtedly solely linked to the MSC peak but also to a longer erosion phase. In western Sardinia margin, as in the Oristano Gulf, Late Miocene marine limestones belonging to the TCC exist, and a karstic plateau that developed at their top has also been interpreted as the MES (Cornée et al., 2008). Moreover, similitudes of marine Pliocene infilling the MES in both study areas favor the interpretation of at least the top part of the continental clastic of Orosei as markers of the MSC continentalization time-interval.

In the peripheral basins (Boudinar in Morocco, Sorbas onland in Spain) the MES was also proved to form in subaerial settings above the TCC. Its geometry is only locally wellpreserved, when overlain by continental clastics deposited before the Zanclean reflooding (Do Couto et al., 2015; Clauzon et al., 2015; Cornée et al., 2016), with incisions suggesting that a fluvial network shaped the landscape during the peak of the MSC. The debris flows (Fig. 5B) deposited above the erosion surface in Eastern Sardinia seem to be an equivalent to those continental deposits.

Offshore, gravity instabilities are also observed on the Balearic Islands slope domain within the MSC unit (Fig. 3B; Maillard et al., 2014), but they show raft deformation typical of gliding processes that could be explained by an evaporitic nature of the MSC unit (BU in this case). Some thin detrital units have been reported locally on the lower slope (Maillard et al., 2006) interpreted as large-scale marine collapse deposits (Cameselle and Urgeles, 2017). Similar thin and local detrital units are also recorded along the Sardinia margin (Lymer et al., 2018) outside of the deep Orosei valley. In both areas, detritals are poorly developed offshore, mainly because of the absence of large drainage networks from the islands (Sardinia and Balearic Islands). Another reason for this scarcity of detrital deposits could be the onshore destabilization evidenced by the gravity deposits trapping the sediments upstream with poor horizontal displacements. In places where they appear offshore, the clastics are often interbedded within the MSCunits. They pass laterally to the MES, proving once again polygenic character of the erosion onshore and on the slope domains, lasting the entire Salinity Crisis peak.

\subsection{Meaning of the depth of the MES}

The MES/MSC deposits limit offshore appears from 500 to $1000 \mathrm{~m}$ depth on the Ibiza slopes whereas it occurs at about 2000 to $2500 \mathrm{~m}$ depth on the Eastern Sardinia margin (Fig. 1B). The depth is also different on each side of the Ibiza Island, deeper on the Valencia side that is connected to deeper basins, shallower on the Balearic side where MSC sub-basins are perched at different depths on the Promontory. These small intermediate-depth sub-basins could have been partially closed and disconnected from the deep basins evaporites (Driussi et al., 2015), at least for precipitation of the MU (Fig. 1), supporting the hypothesis of different depth for the deposition of the evaporites (hypothesis of stepped sub-basins, Cita and Ryan, 1978; Ryan, 2008; Maillard et al., 2014; Roveri et al., 2014; Pellen et al., 2016). Late Miocene onshore deposits of the NE Ibiza Island, currently laying at 0 to $30 \mathrm{~m}$ height, formed in the near-shore environment, running out the possibility of large vertical post-MSC motion that could have explained the present-day different depth of the evaporites occurrences on both sides of the island. Possible maximal $40 \mathrm{~m}$ uplift of Unit 4 also minimizes the possible vertical movements. This is in accordance with preliminary backstripping results on the Balearic Promontory showing that the pre-MSC paleo-topography was not very different from the present-day bathymetry (Mas et al., 2018; Heida et al., 2019). In Eastern Sardinia, rifting was completed by the beginning of the MSC, and resulted in the isolation of the East Sardinian basin, thus already deep during the MSC. Some post-rift reactivation has occurred locally in that domain but only minor vertical motions have affected the margin after the beginning of the oceanic spreading in the deep basin (e.g. Lymer et al., 2018). We have thus to assume that the MSC sedimentary units developed in several terraces set up during the rifting.

Consequently, both study areas support the hypothesis of the existence of sub-basins perched at different depth during the Crisis, possibly infilled with different evaporite successions and possibly in a diachronic way. Together with the subaerial erosion, these are arguments for disconnection of some sub-basins during the acme of the crisis, incompatible with high stand sea level, at least during the entire length of the crisis. To conclude, during the MSC, both areas were moreover in post-tectonic context: post Betic compression for Ibiza and post-Tyrrhenian rifting for the Sardinia Eastern margin. Tectonic deformation exists locally but is regionally weak during the Late Miocene/Pliocene and, unlike proposed explanations (Roveri et al., 2019), vertical movements 
(uplift/subsidence) are not the main trigger mechanism, at least at large scale, to explain the present-day different depth of the MSC deposits. Nevertheless, isostatic rebound must be taken into account in the MSC scenario (as shown in Rabineau et al., 2014) and vertical movements will be carefully studied in the integrated project SALTGIANT - Understanding the Mediterranean Salt Giant [Marie Sklodowska-Curie Actions-Innovative Training Networks (ITN)].

\section{Conclusion}

The MES, Margin Erosion Surface of the Messinian Salinity Crisis, is described for the first time onland Ibiza and East Sardinia in the Orosei area, showing its existence onland outside of large river systems and outside of peripheral basins. In both cases, the MES extends offshore and passes laterally to MSC units down the slope, the depth of the transition being different in each margin. This also demonstrates onland the polygenic character of the erosion that has been proposed for the offshore MES.

In both cases, the MES is overlain by marine Pliocene and aeolian Plio-Pleistocene sediments, particularly well observed in the valleys. In the Orosei area, Late Pliocene to Quaternary lava flows permitted to preserve those deposits whereas, in Ibiza, Pliocene marine deposits occurred locally filling small valleys and covering the top of Late Miocene cliffs.

The erosion is incised in various units ranging from preMSC unit down to the basement in both cases. Onland Ibiza, incisions affected Mesozoic and overlying marine Late Miocene series identified as regional known units. The erosion is clearly post-TCC. Onland eastern Sardinia, it affected Mesozoic and Paleogene units but marine Late Miocene units are missing.

The MES formed during the MSC peak is a subaerial erosional surface as testified by evidence of continentalization events: karstification of the surface, detritals and continental deposits linked to gravity instabilities, emplacement of aeolian dunes and paleosols onshore. These thin and local continental deposits provide new evidence for a regression phase and, where present, preserved the original geometry of the MES.

Acknowledgements. The authors acknowledge the French "Action Marges" INSU program for the financial support of this project. The authors thank G. Mas-Gornal for having shared discussions in Ibiza on the field and Francisco Sierro for foraminiferas determination. Aloe Hok-Schlagenhauf postedited the English style that deeply enriched the manuscript. We also wish to express our gratitude to Marina Rabineau and an anonymous reviewer who provided very useful comments that greatly improved the manuscript.

\section{References}

Bache F, Olivet JL, Gorini C, Rabineau M, Baztan J, Aslanian D, et al. 2009. Messinian erosional and salinity crises: view from the Provence Basin (Gulf of Lions, Western Mediterranean). Earth Planet Sci Lett 286: 139-157.

Bache F, Popescu S-M, Rabineau M, Gorini C, Suc J-P, Clauzon G, et al. 2012. A two-step process for the reflooding of the Mediterranean after the Messinian Salinity Crisis. Basin Res 24: $125-153$.
Bache F, Gargani J, Suc J-P, Gorini C, Rabineau M, Popescu SM, et al. 2015. Messinian evaporite deposition during sea-level rise in the Gulf of Lion (Western Mediterranean). Marine and Petroleum Geology 66: 262-277.

Barber PM. 1981 Messinian subaerial erosion of the Proto-Nile Delta. Marine Geology 44: 253-272.

Beccaluva L, Campredon R, Feraud G, Macciotta G. 1983. Etude des relations entre volcanisme plio-quaternaire et tectonique en Sardaigne à l'aide de l'analyse structurale des dykes. Bull Volcanol 46(4): 365-379.

Bourillot R, Vennin E, Rouchy J-M, Durlet C, Rommevaux V, Kolodka C, et al. 2010. Structure and evolution of a Messinian mixed carbonate siliclastic platform: the role of evaporites (Sorbas Basin, South-east Spain). Sedimentology 57: 477-512.

Braga JC, Martin JM, Riding R, Aguirre J, Sanchez-Almazo IM, Dinares-Turell J. 2006. Testing models for the Messinian salinity crisis: the Messinian record in Almería, SE Spain. Sedimentary Geology 188-189: 131-154.

Calvino F, Dieni I, Ferasin F, Piccoli G. 1972. Note illustrative alla Carta Geologica de Italia, Foglio 195-Orosei (Sardegna), Roma, pp. 9-39.

Cameselle AL, Urgeles R. 2017. Large-scale margin collapse during Messinian early sea-level drawdown: the SW Valencia trough, NW Mediterranean. Basin Research 29: 576-595.

Chumakov I. 1973. Pliocene and Pleistocene deposits of the Nile valley in Nubia and Upper Egypt. In : Ryan WBF, Hsü KJ, et al., eds. Initial Report of Deep Sea Drilling Project, vol.13. Washington: U.S. Government Printing Office, pp. 1242-1243.

CIESM, Anton J, CaGatay MN, De Lange G, Flecker R, Gaullier V, Gunde-Cimerman N, et al. 2008. Executive summary. In: Briand F, ed. The messinian salinity crisis from mega-deposits to microbiology-A consensus report, CIESM Workshop Monographs, vol. 33, pp. 7-28.

Cita M, Ryan W. 1978. Messinian erosional surfaces in the Mediterranean. Marine Geology 27: 193-365.

Clauzon G. 1973. The eustatic hypothesis and the pre-Pliocene cutting of the Rhône valley. In: Ryan WBF, Hsü KJ, eds. Initial Report of the Deep Sea Drilling Project, pp. 1251-1256.

Clauzon G. 1982. Le canyon Messinien du Rhône: une preuve décisive du «desiccated deep-basin model» (Hsü, Cita and Ryan, 1973). Bull Soc Géol Fr 24(3): 597-610.

Clauzon G, Suc JP, Do Couto D, Jouannic G, Melinte-Dobrinescu MC, Jolivet L, et al. 2015. New insights on the Sorbas Basin (SE Spain): The onshore reference of the Messinian Salinity Crisis. Marine and Petroleum Geology 66: 71-100.

Cornée JJ, Saint Martin JP, Conesa G, Münch P, André JP, Saint Martin $\mathrm{S}$, et al. 2004. Correlations and sequence stratigraphic model for Messinian carbonate platforms of the western and central Mediterranean. International Journal of Earth Sciences 93: 621-633.

Cornée JJ, Maillard A, Conesa G, Garcia F, Saint Martin JP, Sage F, et al. 2008. Onshore to offshore reconstruction of the Messinian erosion surface in western Sardinia, Italy: MSC implications. Sedimentary Geology 210(1-2): 48-60.

Cornée JJ, Münch P, Achalhi M, Merzeraud G, Azdimousa A, Quillévéré F, et al. 2016. The Messinian erosional surface and early Pliocene reflooding in the Alboran Sea: New insights from the Boudinar basin, Morocco. Sedimentary Geology 333: 115-129.

Del Olmo WM. 2011. The Messinian in the Gulf of Valencia and Alboran Sea (Spain): paleogeography and paleoceanography implications. Revista de la Sociedad Geológica de España 24: $1-22$.

Del Valle L, Gomez-Pujol LJ, Fornos J, Timar-Gabor A, Anechiteie-Deacu V, Pomar F. 2016. Middle to Late Pleistocene dune fields in rocky coast settings at Cala Xuclar (Eivissa, 
Western Mediterranean): Recognition, architecture and luminescence chronology. Quaternary International.

Dieni I, Massari F, Médus J. 2008. Age, depositional environment and stratigraphic value of the Cuccurue Flores Conglomerate: insight into the Palaeogene to Early Miocene geodynamic evolution of Sardinia. Bull Soc Géol France 179: 51-72.

Do Couto D, Gumiaux C, Jolivet L, Augier N, Lebret Folcher N, Jouannic G, et al. 2015. 3D modelling of the Sorbas Basin (Spain): New constraints on the Messinian Erosional Surface morphology. Marine and Petroleum Geology 66: 101-116.

Doglioni C, Innocenti F, Morellato C, Procaccianti D, Scrocca D. 2004. On the Tyrrhenian sea opening. Memorie Descrittive della Carta Geologica d'Italia 64: 147-164.

Driussi O, Maillard A, Ochoa D, Lofi J, Chanier F, Gaullier V, et al. 2015. Messinian Salinity Crisis deposits widespread over the Balearic Promontory: insight from new High Resolution seismic data. Marine and Petroleum Geol 66: 41-54. DOI: 10.1016/j. marpetgeo.2014.09.008.

Durand-Delga M, Freneix S, Magné J, Méon H, Rangheard Y. 1993. La série saumâtre et continentale d'âge Miocène moyen et supérieur d'Eivissa (ex-Ibiza, Baléares). Acta Geol Hisp Barcelona 28(1): 33-46.

Esteban M. 1979. Significance of the upper Miocene coral reefs of the Western Mediterranean. Palaeogeography, Palaeoclimatology, Palaeoecology 29: 169-188.

Esteban M, Braga JC, Martin JC, Santisteban C. 1996. An overview of Miocene reefs from the Mediterranean areas: general trends and facies models. In: Franseen EK, Esteban M, Ward W, Rouchy JM, eds. Models for carbonate stratigraphy from miocene reef complexes of Mediterranean. SEPM Concepts Sedimentol Paleontol, vol. 5, pp. 3-53.

Escutia C, Maldonado A. 1992. Paleogeographic implications of the Messinian surface in the Valencia trough, north-western Mediterranean sea. In: Banda E, Santanach P, eds. Geology and geophysics of the Valencia trough, Western Mediterranean. Tectonophysics 203: 263-284.

Field ME, Gardner JV. 1991. Valencia gorge: possible Messinian refill channel for the western Mediterranean Sea. Geology 19: 1129-1132.

Garcia M, Maillard A, Aslanian D, Rabineau M, Alonso B, Gorini C, et al. 2011. The Catalan margin during the Messinian Salinity Crisis: Physiography, morphology and sedimentary record. Marine Geology 284: 158-174.

Gaullier V, Chanier F, Lymer G, Vendeville B, Maillard A, Thinon I, et al. 2014. Salt tectonics and crustal tectonics along the Eastern Sardinian margin, Western Tyrrhenian: New insights from the "METYSS 1" cruise. Tectonophysics 615-616: 69-84.

Gautier F, Clauzon G, Suc JP, Cravatte J, Violenti D. 1994. Age et durée de la crise de salinité messinienne. Compte Rendu de l'Académie des Sciences de Paris 318(2): 1103-1109.

Giresse P, Bassetti M-A, Chanier F, Gaullier V, Maillard A, Thinon I, et al. 2015. Depositional environment and age of some key Late Pliocene to Early Quaternary deposits on the underfilled Cedrino paleovalley (Orosei): Insight into the Neogene geodynamic evolution of Sardinia. Quaternary International 357: 220-236.

Gueguen E, Doglioni C, Fernandez M. 1998. On the post-25 Ma geodynamic evolution of the western Mediterranean. Tectonophysics 298: 259-269.

Guennoc P, Gorini C, Mauffret A. 2000. Histoire géologique du golfe $\mathrm{du}$ Lion et cartographie du rift oligo-Aquitanien et de la surface messinienne. Géol France 3: 67-97.

Gvirtzman Z, Manzi V, Calvo R, Gavrielli I, Gennari R, Lugli S, et al. 2017. Intra-Messinian truncation surface in the Levant Basin explained by subaqueous dissolution. Geology 45: 915-918.
Hardie LA, Lowenstein TK. 2004. Did the Mediterranean Sea dry out during Miocene? A reassessment of the evaporite evidence from DSDP Legs 13 and 42A cores. Journal of Sed. Research 74: 453-461.

Heida H, Garcia-Castellanos D, Jimenéz-Munt I, Maillard A, Lofi J, Raad F. 2019. Topography of the Balearic Promontory during the Messinian Salinity Crisis: Isostatic response to desiccation and evaporite deposition. In : TOPO-EUROPE CONFERENCE, 5-10 May 2019, Granada.

Hsü KJ, Ryan WBF, Cita MB. 1973. Late Miocene desiccation of the Mediterranean. Nature 242: 240-244.

Jolivet L, Augier R, Robin C, Suc J-P, Rouchy J-M. 2006. Lithospheric-scale geodynamic context of the Messinian salinity crisis. Sedimentary Geology 188-189: 9-33.

Lanaja JM. 1987. Contribucion de la exploracion petrolifera al conocimiento de la geologia de Espana. Madrid: IGME. Serv. Publishers Minnis. Industri. Energ.

Leroux E, Rabineau M, Aslanian D, Gorini C, Bache F, Moulin M, et al. 2015. Post-rift evolution of the Gulf of Lion margin tested by stratigraphic modelling. Bulletin de la Société Géologique de France 186: 291-308.

Leroux E, Aslanian D, Rabineau M, Gorini C, Rubino J-L, Poort J, et al. 2019. ATLAS of the stratigraphic markers in the Western Mediterranean with focus on the Messinian, Pliocene and Pleistocene of the Gulf of Lion, 77 p. + DVD, CCGM-CGMW editors. DOI: 10.14682/2019GULFLIONATL.

Lézin C, Driussi O, Bourillot R, Maillard A, Chanier F, Odonne F. 2014. Le Miocène terminal de l'île d'Ibiza : étude des dépôts liés à la crise messinienne. Poster, $24^{e}$ Réunion des Sciences de la Terre (RST), 27-31 octobre, Pau.

Lézin C, Maillard A, Odonne F, Colinet G, Chanier F, Gaullier V. 2017. Tectono-sedimentary evolution of the Miocene-Pliocene series of Ibiza: new onshore evidence of the Messinian Salinity Crisis. IAS octobre 2017, Toulouse.

Lofi J, Gorini C, Berne S, Clauzon G, Dos Reis AT, Ryan WBF, Steckler MS. 2005. Erosional processes and paleo-environmental changes in the western Gulf of Lions (SW France) during the Messinian Salinity Crisis. Marine Geology 217: 1-30.

Lofi J, Deverchère J, Gorini C, Gaullier V, Gillet $\mathrm{H}$, Guennoc $\mathrm{P}$, et al. 2011. Atlas of the Messinian Salinity Crisis markers in the Mediterranean and Black Seas. Mém Soc Géol Fr 179: 72, World Geological Map Commission.

Lofi J, et al. 2018. Seismic atlas of the Messinian Salinity Crisis markers in the Mediterranean and Black seas, vol. 2, Mém Soc Géol Fr 181, and World Geological Map Commission, 72 p.

Lugli S, Manzi V, Roveri M, Scheiber C. 2010. The Primary Lower Gypsum in the Mediterranean: a new facies interpretation for the first stage of the Messinian salinity crisis. Palaeogeography, Palaeoclimatology, Palaeoecology 297: 83-99.

Lymer G, Lofi J, Maillard A, Thinon I, Gaullier V, Sage F, et al. 2018. Seismic markers of the Messinian Salinity Crisis (MSC) along the East-Sardinian margin: new constraints on margin's evolution. Marine Geology 398: 1-21.

Maillard A, Mauffret A. 2006. Relationship between erosion surfaces and Late Miocene Salinity Crisis deposits in the Valencia Basin (northwestern Mediterranean): evidence for an early sea-level fall. Terra Nova 18: 321-329.

Maillard A, Gorini C, Mauffret A, Sage F, Lofi J, Gaullier V. 2006. Offshore evidence of polyphase erosion in the Valencia Basin (Northwestern Mediterranean): scenario for the Messinian Salinity Crisis. In : Rouchy JM, Suc JP, Ferrandini J, eds. The Messinian Salinity Crisis re-visited. Sedimentary Geology 188-189: 69-91.

Maillard A, Driussi O, Lofi J, Briais A, Chanier F, Hübscher C, et al. 2014. A complete record of the Messinian markers in the SW 
Mallorca area (Balearic Promontory, Spain). Marine Geol 357: 304-302. DOI: 10.1016/j.margeo.2014.10.001.

Malinverno A, Ryan W. 1986. Extension in the Tyrrhenian Sea and shortening in the Apennines as result of arc migration driven by sinking of the lithosphere. Tectonics 5: 227-245.

Manzi V, Gennari R, Hilgen F, Krijgsman W, Lugli S, Roveri M, et al. 2013. Age refinement of the Messinian salinity crisis onset in the Mediterranean. Terra Nova 25: 315-322.

Manzi V, Gennari R, Lugli S, Persico D, Reghizzi M, Roveri M, et al. 2018. The onset of the Messinian salinity crisis in the deep Eastern Mediterranean Basin. Terra Nova 189-198. DOI: 10.1111/ter.1232530.

Mas GY, Fornós JJ. 2012. La Crisis de Salinidad del Messiniense en la cuenca sedimentaria de Palma (Mallorca, Islas Baleares); The Messinian Salinity Crisis Record in the Palma basin (Mallorca, Balearic Islands). Geogaceta 52: 57-60.

Mas G, Maillard A, Alcover JA, Fornós JJ, Bover P, Torres-Roig E. 2018. Terrestrial colonization of the Balearic Islands: New evidence for the Mediterranean sea-level drawdown during the Messinian Salinity Crisis. Geology 46: 527-530. DOI: 10.1130/ G40260.1.

Mauffret A, Montadert L, Lavergne M, Wilm C. 1978. Geological and geophysical setting of DSDP Site 372 (Western Mediterranean). In: Montadert L, Hsü KJ, eds. Initial Reports of the Deep Sea Drilling Project, vol. 42. Washington DC: U.S. Government Printing Office, pp. 889-896.

Micallef A, Camerlenghi A, Garcia-Castellanos D, Cunarro Otero D, Gutscher MA, Barreca G, et al. 2018. Evidence of the Zanclean megaflood in the eastern Mediterranean Basin. Nature Scientific Reports. DOI:10.1038/s41598-018-19446-3.

Miller KG, Kominz MA, Browning JV, Wright JD, Mountain GS, Katz ME, et al. 2005. The Phanerozoicrecord of global sea-level change. Science 310: 1293-1298.

Montadert L, Letouzey J, Mauffret A. 1978. Messinian event: seismic evidence. In: Initial Reports of the Deep Sea Drilling Project, vol. 42(1). Washington, DC: US Govt. Printing Office, pp. 10371050 .

Ochoa D, Sierro FJ, Lofi J, Maillard A, Flores JA, Suarez M. 2015. Synchronous onset of the Messinian evaporite precipitation: First Mediterranean offshore evidence. EPSL 427: 112-124. DOI: 10.1016/j.eps1.2015.06.059.

Odonne F, Maillard A, Lézin C, Chanier F, Gaullier V, Guillaume D. 2019. Large-scale boudinage of Late Miocene platform series triggered by margin collapse during the Messinian Salinity Crisis (Ibiza Island, Spain). Marine and Petroleum Geology 109: 852867. DOI: 10.1016/j.marpetgeo.2019.06.058.

Orszag-Sperber F, Caruso A, Blanc-Valleron MM, Merle D, Rouchy JM. 2009. The onset of the Messinian salinity crisis: Insights from Cyprus sections. Sedimentary Geology 217: 52-64.

Pellen R, Aslanian D, Rabineau M, Leroux E, Gorini C, Silenziario C, et al. 2016. The Minorca Basin: a buffer zone between the Valencia and Liguro-Provençal Basins (NW Mediterranean Sea). Terra Nova 28: 245-256.

Pellen R, Aslanian D, Rabineau M, Suc J-P, Gorini C, Leroux E, et al. 2019. The Messinian Ebro River incision. Global and Planetary Changes 181. DOI: 10.1016/j.gloplacha.2019.102988.

Pomar L. 2001. Ecological control of sedimentary accommodation: evolution from a carbonate ramp to rimmed shelf, Upper Miocene, Balearic Islands. Paleogeography, Palaeoclimatology, Palaeoecology 175(1-4): 249.

Pomar L, Ward WC, Green DG. 1996. Upper Miocene Reef Complex of the Llucmajor area, Mallorca, Spain.). In: Franseen E, Esteban M, Ward WC, Rouchy JM, eds. Models for carbonate stratigraphy from miocene reef complexes of Mediterranean regions. Soc Econ
Paleontol Mineral, Concepts in Sedimentology and Palaeontology Serie, 5: 191-225.

Prada M, Ranero CR, Sallarès V, Zitellini N, Grevemeye I. 2016. Mantle exhumation and sequence of magmatic events in the Magnaghi-Vavilov Basin (Central Tyrrhenian, Italy): New constraints from geological and geophysical observations. Tectonophysics 689: 133-142.

Rabineau M, Leroux E, Aslanian D, Bache F, Gorini C, Moulin M, et al. 2014. Quantifying Subsidence and Isostasy using paleobathymetric markers: example from the Gulf of Lion. EPSL 388: 353-366. DOI: 10.1016/j.eps1.2013.11.059.

Riding R, Braga JC, Martín JM. 1999. Late Miocene Mediterranean desiccation: topography and significance of the "Salinity Crisis" erosion surface on-land in southeast Spain. Sedimentary Geology 123: $1-7$.

Roca E. 2001. The Northwest-Mediterranean basin (Valencia Trough, Gulf of Lions and Liguro-Provencal basins): structure and geodynamic evolution. In: Ziegler PA, Cavazza W, Robertson AFH, eds. Peri-Tethys memoir, IGCP 369: Peri Tethyan Rift/ Wrench Basins and Passive Margins. Mem Mus Natl Hist Nat, Paris, pp. 671-706.

Rosell L, Orti F, Kasprzyk A, Playà E, Marek Peryt T. 1998. Strontium geochemistry of Miocene primary gypsum: Messinian of Southeastern Spain and Sicily and Badenian of Poland. Journal of Sedimentary Research 68: 63-79.

Rouchy JM, Caruso A. 2006. The Messinian salinity crisis in the Mediterranean basin: A reassessment of the data and an integrated scenario. Sedimentary Geology 188-189: 35-67.

Roveri M, Manzi V. 2006. The Messinian salinity crisis: looking for a new paradigm? Palaeogeography, Palaeoclimatology, Palaeoecology 238: 386-398.

Roveri M, Gennari R, Lugli S, Manzi V. 2009. The Terminal Carbonate Complex: the record of sea-level changes during the Messinian salinity crisis. GeoActa 8: 57-71.

Roveri M, Lugli S, Manzi V, Gennari R, Schreiber C. 2014. Highresolution strontium isotope stratigraphy of the Messinian deep Mediterranean basins: Implications for marginal to central basins correlation. Marine Geol. DOI: 10.1016/j.margeo.2014.01.002.

Roveri M, Gennari R, Ligi M, Lugli S, Manzi V, Reghizzi M. 2019. The synthetic seismic expression of the Messinian salinity crisis from onshore records: implications for shallow- to deep-water correlations. DOI: 10.1111 /bre. 12361 .

Ryan WBF. 2008. Modeling the magnitude and timing of evaporative drawdown during the Messinian salinity crisis. Stratigraphy 5(1): 227-243.

Ryan WBF. 2009. Decoding the Mediterranean Salinity Crisis. Sediment 56(1): 95-136.

Ryan WBF, Cita MB. 1978. The nature and distribution of Messinian erosion surfaces, indicators of a several-kilometer-deep Mediterranean in the Miocene. Marine Geology 27: 193-230.

Sabat F, Gelabert B, Rodriguez-Perea A, Giménez J. 2011. Geological structure and evolution of Mallorca: Implications for the origin of the Western Mediterranean. Tectonophysics 510: 217-238.

Sage F, Von Gronefeld G, Deverchere J, Gaullier V, Maillard A, Gorini C. 2005. Seismic evidence for Messinian detrital deposits at the Western Sardinia margin, Northwestern Mediterranean. Marine and Petroleum Geology 22: 757-773.

Sanz De Galdeano C. 1990. Geologic evolution of the Betic Cordilleras in the Western Mediterranean, Miocene to the present. Tectonophysics 172: 107-119.

Sartori R, Carrara G, Torelli L, Zitellini N. 2001. Neogene evolution of the southwestern Tyrrhenian Sea (Sardinia Basin and Western bathyal plain). Marine Geology 175: 47-66. 
Savoye B, Piper DJW. 1991. The Messinian event on the margin of the Mediterranean Sea in the Nice area, southern France. Mar Geol 97: 279-304.

Sierro F, Flores J, Francés G, Vazquez A, Utrilla R, Zamarreño I, et al. 2003. Orbitally-controlled oscillations in planktic communities and cyclic changes in western Mediterranean hydrography during the Messinian. Palaeogeogr Palaeoclimatol Palaeoecol 190: 289-316.

Soria JM, Caracuel JE, Corbí H, Dinarès-Turell J, Lancis C, TentManclús JE, et al. 2008. The Messinian-early Pliocene stratigraphic record in the southern Bajo Segura Basin (Betic Cordillera,
Spain): implications for the Mediterranean salinity crisis. Sedimentary Geology 203(3): 267-288.

Thinon I, Guennoc P, Maillard A, Serrano O, Lasseure E, Rehault JP. 2016. Seismic markers of the Messinian Salinity Crisis in an intermediate-depth basin: Data for understanding the Neogene evolution of the Corsica Basin (northern Tyrrhenian Sea). Marine and Petrol Geol 77: 1274-1296.

Urgeles R, Camerlenghi A, Garcia-Castellanos D, De Mol B, Garcés M, Vergés J, et al. 2011. New constraints on the Messinian sealevel drawdown from 3D seismic data of the Ebro Margin, western Mediterranean. Basin Research 23: 123-145.

Cite this article as: Maillard A, Gaullier V, Lézin C, Chanier F, Odonne F, Lofi J. 2020. New onshore/offshore evidence of the Messinian Erosion Surface from key areas: The Ibiza-Balearic Promontory and the Orosei-Eastern Sardinian margin, BSGF - Earth Sciences Bulletin 191: 9. 